\title{
KEPUTUSAN PEMBELIAN ULANG MELALUI KEPUASAN KONSUMEN SEBAGAI VARIABEL INTERVENING DITINJAU DARI KUALITAS PRODUK DAN KUALITAS PELAYANAN PADA PASAR TRIWINDU SURAKARTA
}

\author{
Ayu Wardani, Sri Hartono, Eny Kustiyah \\ Program Studi Manajemen Fakultas Ekonomi Universitas Islam Batik Surakarta \\ Email : ayuw16074@gmail.com
}

\begin{abstract}
The purpose of this study was to analyze whether the repurchase decision by product quality and service quality in Surakarta Triwindu Market.The population in this study is all consumers in Surakarta Triwindu Market. The sampling technique was accidental sampling, with 100 respondents.Data collection using a Likert scale questionnaire to measure respondents' answers.Path analysis to identify the relationship between product quality, service quality on repurchase decisions through customer satisfaction.The results showed that repurchase decisions through customer satisfaction were not significantly affected by product quality, while service quality on repurchase decisions through customer satisfaction significantly affected the Surakarta Triwindu Market.
\end{abstract}

Keyword: Product Quality, Service Quality, Consumer Satisfaction, Repurchase Decisions

\section{PENDAHULUAN}

Kebiasan, norma dan adat sudah menjadi hal yang bagian dari kehidupan sosial masyarakat seperti halnya pada pasar sebagai sarana kegiatan perekonomian yang memenuhi kebutuhan masyarakat.

Pedagang dan pihak-pihak yang terkait harus bahu membahu meningkatkan kepuasan konsumen yang berbelanja agar tetap bertahan membeli dan memenuhi kebutuhan produk mereka dari pedagang tradisional (Saputra, 2015), hubungan antara produsen dan konsumen pun menjadi bermanfaat bernuansa harmonis, akan berpengaruh positif menciptakan pembelian ulang, loyal konsumen, serta dapat membentuk suatu rekomendasi word-of-mouth yang menguntungkan (Utama dan Ngatno, 2017) tanpa ada yang ditutup-tutupi sehingga secara tidak langsung konsumen membantu menawarkan produk yang sedang dipasarkan.

Ketika seseorang berbelanja, pertama kali yang sering diperhatikan tidak lain kualitas produk berarti kinerja suatu produk yang dilihat dari bagaimana produk tersebut menjalankan fungsinya (Sugiharto, 2015). Disamping memperhatikan kualitas produk pasar serta memberikan pelayanan yang baik, cepat, tepat dan ramah berpengaruh terhadap kepuasan konsumen sehingga kepuasaan yang dirasakan membuat ingin menikmati kembali jasa pelayanan.

Dari pengamatan dan wawancara peneliti dengan pengunjung, peneliti menemukan bahwa tidak tertalu ramai pengunjung tetapi tetap berdiri sampai sekarang dan bertahan dalam persaingan yang saat ini kemajuan semakin pesat dan yang menjadi hal menarik untuk diteliti terdapat beberapa lapak pada bagian dinding atau kusen tertuliskan nama serta nomor pedangang yang bisa dihubungi konsumen

\section{LANDASAN PUSTAKA}

\section{Kepuasan Konsumen}

Rasa atau perasaan yang ada pada diri konsumen selama menggunakan atau setelah mengkonsumsi suatu produk (Purwanto, 2010 : 65). Adapun pendapat Kotler (2012:150) kepuasan konsumen adalah apa yang dirasakan oleh konsumen baik senang maupun kecewa setelah mengkonsumsi suatu produk dengan memandingkan hasil real dengan yang diharapkan. 
Kepuasan Konsumen Dapat disimpulkan kepuasan konsumen adalah Rasa atau perasaan yang ada pada diri konsumen setelah mengkonsumsi suatu produk, melalui kinerja pedagang, apa yang diharapkan oleh konsumen sesuai dengan harapan, serta mendapat rekomendasi dari orang lain.

\section{Keputusan Pembelian Ulang}

Keputusan pembelian Ulang (Kotler, 2012 : 202), pengalaman konsumen dalam mempelajari, melakukan pemilihan dan siap untuk melakukan pembelian ulang dalam menggunakan produk.

Adapun pendapat Suharso (2010: 83), mengemukakan keputusan pembelian situasi dimana konsumentelah menentukan pilihan, melakukan pembelian produk serta mengkonsumsinya. Suharno (2010:96) mengemukakan keputusan konsumen dimana mereka telah menentukan choice produk, melakukan pembelian produk serta mengkonsumsi produk tersebut.

Dapat disimpulkan keputusan pembelian ulang yaitu tingkah laku konsumen dalam choice dan memutuskan to buying atau tidak terhadap suatu produk dan siap melakukan pembelian ulang dalam menggunakan produk.

Berikut Tahap-tahap pengambilan keputusan konsumen dalam buying (Kottler dan Keller, 2016 : 195), antara lain :Problem Recognition, Search, Alternative Evolution, Choice, and Out Comes.

\section{Kualitas Produk}

Karakter dari suatu produk ataupun jasa bergantung dari kemampuan dalam memuaskan kebutuhan yang dinyatakan (Kotler, 2009 : 143). Kondisi dimana produk yang dinilai sesuai dengan standar ukur yang telah ditetapkan (Handoko, $2002: 23$ ). Kemampuan suatu perusahaan untuk memberikan karakteristik suatu produk maka konsumen dapat mengenali produk (Sciffman dan Kanuk, 2007). Strategi mengalahkan pesaing dengan menunjukkan dari berbagai fungsi meliputi endurance, comrade, and exact dalam penggunaan (Kotler dan Amstrong, 2008).

Kualitas produk yaitu gabungan dari seluruh ciri-ciri produk meliputi marketing, planning, production, and keeping untuk memenuhi harapan- harapan konsumen.

Adapun tiga hal yang mendasar mempengaruhi suatu produk yaitu price, supply, and quality. Adapun dimensi kualitas produk menurut yang lain (Pride dan Ferrel, 2010 : 317), sebagai berikut :

a) Level of quality, jumlah kualitas yang dimiliki oleh suatu produk dengan membandingkan antara produk satu dengan yang lain

b) Consistency of quality, mengacu pada sejauh mana suatu produk memiliki kualitas pada level yang sama dalam waktu lama. Konsisten berarti memberikan kualitas yang mereka harapan setiap ketika mereka membeli suatu produk.

\section{Kualitas Pelayanan}

Kualitas yaitu ukuran seberapa baik tingkat pelayanan yang mampu diberikan sesuai yang diinginkan konsumen (Wijaya, 2011 : 152). Kualitas jasa merupakan tingkat keunggunan untuk memenuhi want and needkonsumen. Baik tidaknya tergantung kepada kemampuan produsen dalam memenuhi hope consument secara consistency (Arief, 2007 : 118).Pelayanan umun yaitu kegiatan yang berlandaskan faktor melalui system, prosedural, and method tertentu untuk memenuhi kebutuhan konsumen. 
Menurut Kasmir (2017 : 12) pelayanan yaitu tindakan perilaku somebody or organization dengan memberikan kepuasaan kepada konsumen maupun sesama produsen. Kualitas pelayanan dapat diartikan sebagai perbedaan sejauh mana antara real and hope konsumen atas service yang mereka dapatkan. Beberapa kriteria penilaian kualitas pelayanan (Adam, 2015 : 14) antara lain Reliability, Responsiveness, Assurance, Empathy, and Tangibles.

\section{HIPOTESIS}

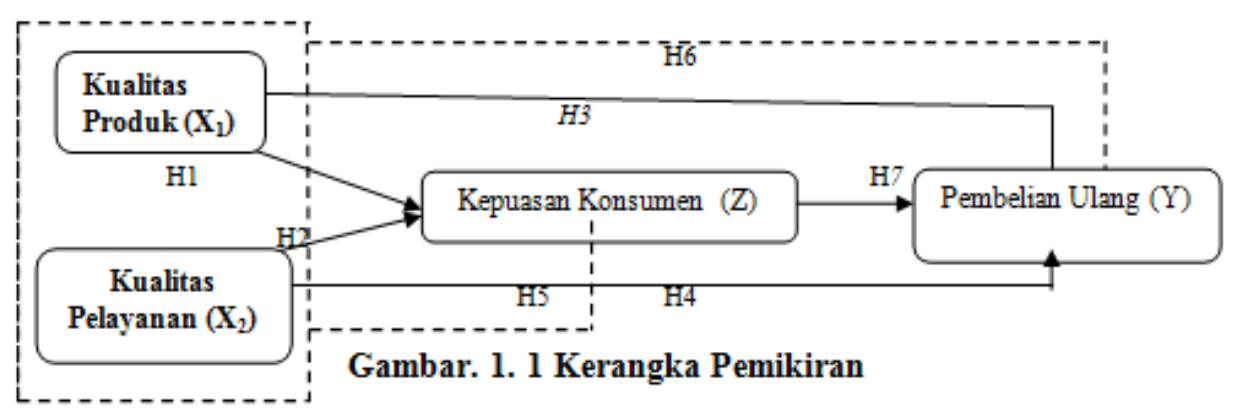

Hipotesis penelitian ini sebagai berikut:

$\mathrm{H}_{1}$ : Ada pengaruh kualitas produk terhadap kepuasan konsumen pada Pasar Triwindu Surakarta.

$\mathrm{H}_{2}$ : Ada pengaruh kualitas pelayanan terhadap kepuasan konsumen pada Pasar Triwindu Surakarta.

$\mathrm{H}_{3}$ : Ada pengaruh kualitas produk terhadap keputusan pembelian ulang pada Pasar Triwindu Surakarta.

$\mathrm{H}_{4}$ : Ada pengaruh kualitas pelayanan terhadap keputusan pembelian ulang pada Pasar Triwindu Surakarta.

$\mathrm{H}_{5}$ : Ada pengaruh kualitas produk dan kualitas pelayanan terhadap kepuasan konsumen pada Pasar Triwindu Surakarta.

$\mathrm{H}_{6}$ : Ada pengaruh kualitas produk dan kualitas pelayanan terhadap keputusan pembelian ulang pada Pasar Triwindu Surakarta.

$\mathrm{H}_{7}$ : Ada pengaruh kepuasan konsumen terhadap keputusan pembelian ulang pada Pasar Triwindu Surakarta.

\section{METODOLOGI PENELITIAN}

Dengan pendekatan kuantitatif yang dilaksanakan di Pasar Triwindu terletak di Ngarsopuro Jl. Diponegoro, Keprabon, Kecamatan Banjarsari, Kota Surakarta, Jawa Tengah berlangsung selama kurang lebih 3 bulan (November 2019 sampai dengan bulan Januari 2020 ).

Teknik pengambilan sampel penelitian ini dengan accidental sampling (secara acak) (Istiatin, 2018: 80). Hasil menunjukkan bahwa jumlah sampel yang diteliti 96,04 responden. Untuk mempermudah penelitan mengambil sampel sebesar 100 responden konsumen Pasar Triwindu Surakarta. 
Instrumen penelitian menggunakan kuisioner dalam skala Likert dari 1-5 dengan bantuan program SPSS for Windows versi 22.0 untuk menganalisis Uji Validitas, Uji Reabilitas, Uji regresi, Uji Hipotesa, Uji aKoefisien Determinasi, Uji Asumsi Klasik, Analisis Jalur.

\section{HASIL DAN PEMBAHASAN}

\begin{tabular}{|c|c|c|c|c|c|}
\hline \multicolumn{6}{|c|}{ Rekapitulasi Analisis Data } \\
\hline Variabel & $\begin{array}{l}\text { Koefisien } \\
\text { Regresi }\end{array}$ & $\begin{array}{l}\text { Koefisien } \\
\text { Korelasi (K) }\end{array}$ & $\begin{array}{l}\text { Koefisien } \\
\text { Determinasi } \\
\left(\mathrm{R}^{2}\right)\end{array}$ & $\begin{array}{l}\text { Kesimpulan (t } \\
\text { hit }>\text { t tabel } \\
1.984\end{array}$ & $\begin{array}{l}\text { Kesimpulan } \\
\text { (F hit > F } \\
\text { tabel 3.931 }\end{array}$ \\
\hline $\begin{array}{l}\text { Kualitas } \\
\text { Produk } \\
\text { Kepuasan } \\
\text { Konsumen }\end{array} \rightarrow$ & 0,502 & 0,563 & (A) 0,317 & 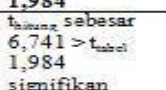 & \\
\hline $\begin{array}{l}\text { Kualitas } \\
\text { Pelayanan } \\
\text { Kepuasan } \\
\text { Konsumen }\end{array}$ & 0,095 & 0,280 & 0,078 & 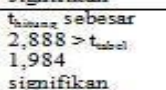 & \\
\hline $\begin{array}{l}\text { Kualitas } \\
\text { Produk } \\
\text { Keputusan } \\
\text { Pembelian }\end{array}$ & 0,477 & 0,459 & 0,211 & 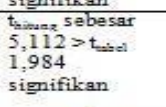 & \\
\hline $\begin{array}{l}\text { Kualitas } \\
\text { Pelayanan -> } \\
\text { Keputusan } \\
\text { Pembelian }\end{array}$ & 0,121 & 0,288 & 0,083 & $\begin{array}{l}t_{\text {tann }} \text { sebesar } \\
2,982>t \text { tusel } \\
1,984 \\
\text { signifikan }\end{array}$ & \\
\hline $\begin{array}{l}\text { Kualitas } \\
\text { Produk dan } \\
\text { Kualitas } \\
\text { Pelayanan } \\
\text { Kepuasan } \\
\text { Konsumen }\end{array}$ & 0,021 & 0,566 & 0,320 & & $\begin{array}{l}F_{\text {timangn }} \text { sebesar } \\
22,838>F_{\text {matel }} \\
3,931 \\
\text { signifikan }\end{array}$ \\
\hline $\begin{array}{l}\text { Kualitas } \\
\text { Produl dan } \\
\text { Kualitas } \\
\text { Pelayanan-> } \\
\text { Keputusan } \\
\text { Pembelian } \\
\text { Ulang }\end{array}$ & 0,052 & 0,472 & 0,223 & & $\begin{array}{l}F_{\text {tinum }} \text { 5ebesar } \\
13,940>F_{\text {tasel }} \\
3,931 \\
\text { signifikan }\end{array}$ \\
\hline $\begin{array}{l}\text { Kepuasan } \\
\text { Konsumen -> } \\
\text { Keputusan } \\
\text { Pembelian } \\
\text { Ulang }\end{array}$ & 0,477 & 0,386 & 0,149 & $\begin{array}{l}t_{\text {himang }} \text { sebesar } \\
0,477<\text { tasel } \\
1,984 \\
\text { signifikan }\end{array}$ & \\
\hline
\end{tabular}

- Kualitas Produk berpengaruh signifikan terhadap Kepuasan Konsumen, dengan dibuktikan hasil uji $t_{\text {hitung }}$ sebesar $6,741>t_{\text {tabel }} 1,984$ dan nilai signifikansi sebesar $0,000<0,05$.

- Kualitas Pelayanan berpengaruh signifikan terhadap Kepuasan Konsumen, dengan dibuktikan hasil uji $t_{\text {hitung }}$ sebesar 2,888 $>t_{\text {tabel }} 1,984$ dan nilai signifikansi sebesar $0,005<0,05$.

- Kualitas Pelayanan berpengaruh signifikan terhadap Kepuasan Konsumen, dengan dibuktikan hasil uji thitung sebesar 5,112 $>\mathrm{t}_{\text {tabel }}$ 1,984 dan nilai signifikansi sebesar $0,000<0,05$.

- Kualitas Pelayanan berpengaruh signifikan terhadap Keputusan Pembelian Ulang, dengan dibuktikan hasil uji $t_{\text {hitung }}$ sebesar 2,982 $>\mathrm{t}_{\text {tabel }}$ 1,984 dan nilai signifikansi sebesar $0,004<0,05$.

- Kualitas Produk dan Kualitas Pelayanan berpengaruh signifikan terhadap Kepuasan Konsumen dengan dibuktikan hasil uji $F_{\text {hitung }}$ sebesar 22,838 $>F_{\text {tabel }}$ 3,931 dan nilai signifikansi sebesar $0,000<0,05$.

- Kualitas Produk dan Kualitas Pelayanan berpengaruh signifikan terhadap Keputusan Pembelian Ulang dengan dibuktikan hasil uji $\mathrm{F}_{\text {hitung }}$ sebesar 13,940 $>\mathrm{F}_{\text {tabel }}$ 3,931 dan nilai signifikansi sebesar $0,000<0,05$.

- Kualitas Pelayanan berpengaruh signifikan terhadap Keputusan Pembelian Ulang, dengan dibuktikan hasil uji $t_{\text {hitung }}$ sebesar $0,477<\mathrm{t}_{\text {tabel }} 1,984$ dan nilai 
signifikansi sebesar $0,005<0,05$.

Tabel 1.3

Rekapitulasi Analisis Jalur

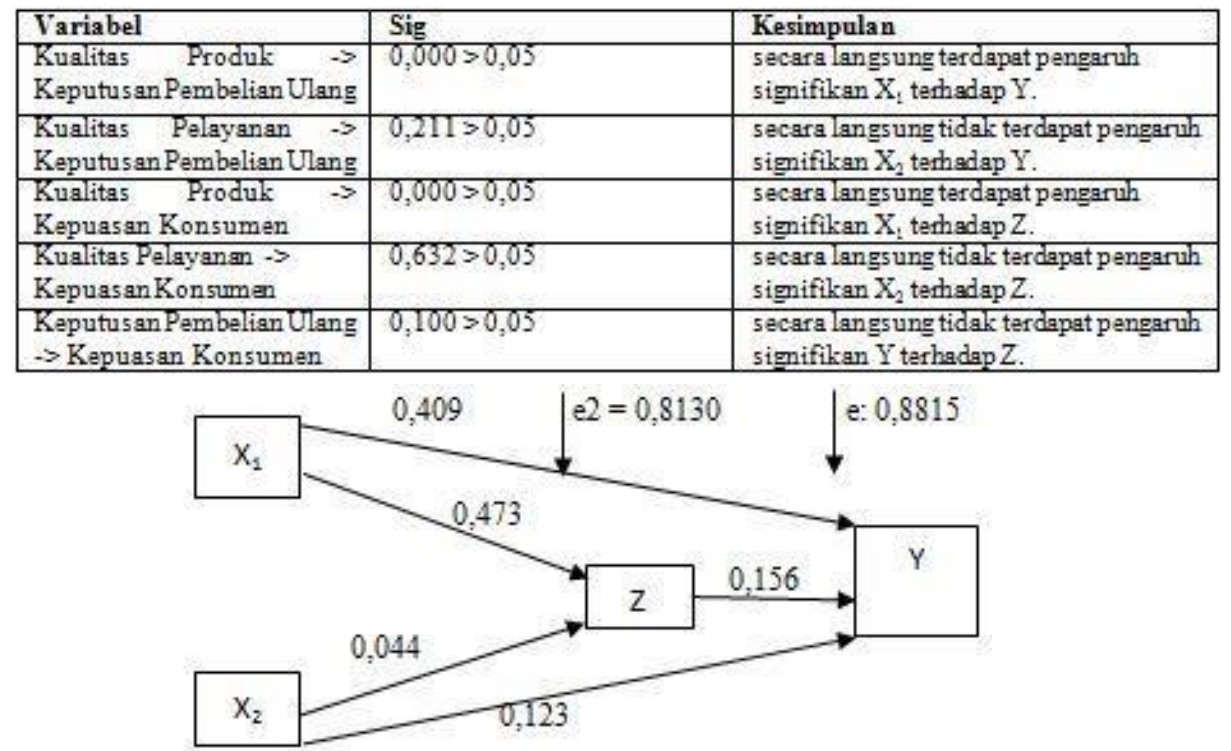

Analisis pengaruh $\mathrm{X}_{1}$ terhadap $\mathrm{Y}$ melalui $\mathrm{Z}$ diketahui pengaruh langsung $\mathrm{X}_{1}$ terhadap $\mathrm{Y}$ sebesar 0,409. Sedangkan pengaruh tidak langsung $\mathrm{X}_{1}$ terhadap $\mathrm{Y}$ melalui $\mathrm{Z}$ (nilai beta $\mathrm{X}_{1}$ terhadap $\mathrm{Z} \times$ nilai beta $\mathrm{Y}$ terhadap $\mathrm{Z}$ ) $0,473 \times 0,156=0,074$. Jadi pengaruh total $X_{1}$ terhadap $Y$ (pengaruh langsung + dengan pengaruh tidak langsung) 0,409 + $0,156=0,565$. Berdasarkan hasil perhitungan nilai pengaruh langsung 0,409 dan pengaruh tidak langsung 0,156 (lebih kecil), maka secara tidak langsung $\mathrm{X}_{1}$ melalui $\mathrm{Z}$ tidak berpengaruh signifikan terhadap $\mathrm{Y}$.

Analisis pengaruh $\mathrm{X}_{2}$ terhadap $\mathrm{Y}$ melalui $\mathrm{Z}$ : diketahui pengaruh langsung $\mathrm{X}_{2}$ terhadap $Y$ sebesar 0,123. Sedangkan pengaruh tidak langsung $X_{2}$ terhadap $Y$ melalui $\mathrm{Z}$ (nilai beta $\mathrm{X}_{2}$ terhadap $\mathrm{Z} \times$ nilai beta $\mathrm{Y}$ terhadap $\mathrm{Z}$ ) $0,044 \times 0,156=0,200$. Jadi pengaruh total $X_{2}$ terhadap $Y$ (pengaruh langsung + dengan pengaruh tidak langsung) $0,123+0,156=0,279$. Berdasarkan hasil perhitungan nilai pengaruh langsung 0,123 dan pengaruh tidak langsung 0,156 (lebih besar), maka secara tidak langsung $\mathrm{X}_{2}$ melalui $\mathrm{Z}$ berpengaruh signifikan terhadap Y.

Dari pembahasan dapat disimpulan bahwa hipotesis yang berbunyi "Keputusan Pembelian Ulang Melalui Kepuasan Konsumen sebagai Variabel Intervening melalui Kualitas Produk dan Kualitas Pelayanan" Ditolak.

Tidak Terdapat Pengaruh Kepuasan Konsumen sebagai intervening hubungan Kualitas Produk terhadap Keputusan Pembelian Ulang pada Pasar Triwindu Surakartadengan dibuktikan nilai pengaruh tidak langsung <nilai pengaruh langsung, maka secara tidak langsung Kualitas Produkmelalui $\mathrm{Z}$ Kepuasan Konsumentidak berpengaruh signifikan terhadap Keputusan Pembelian Ulang.

\section{KESIMPULAN}

a. Adanya pengaruh signifikan varibel Kualitas Produk terhadap Kepuasan Konsumen. 
b. Adanya pengaruh signifikan varibel Kualitas Pelayanan terhadap Kepuasan Konsumen.

c. Adanya pengaruh signifikan variabel Kualitas Produk terhadap Keputusan Pembelian Ulang.

d. Adanya pengaruh signifikan varibel Kualitas Pelayanan terhadap Keputusan Pembelian Ulang.

e. Adanya pengaruh signifikan varibel Kualitas Produk dan Kualitas Pelayanan terhadap Kepuasan Konsumen.

f. Adanya pengaruh signifikan varibel Kualitas Produk dan Kualitas Pelayanan terhadap Keputusan Pembelian Ulang.

g. Adanya pengaruh signifikan varibel Kepuasan aKonsumen terhadap Keputusan Pembelian Ulang.

h. Dari hasil penelitian menunjukkan variabel Kualitas Produk diketahui nilai pengaruh langsung 0,409 dan pengaruh tidak langsung 0,156 (lebih kecil), maka secara tidak langsung Kualitas Produk melalui Kepuasan Konsumen tidak berpengaruh signifikan terhadap Keputusan Pembelian Ulang.

Keterbatasan dalam penelitian ini. Pertama, penelitian hanya terfokuskan pada dua variabel independen yaitu kualitas produk, dan kualitas pelayanan, masih kurang sempurna karena adanya variabel lain yang belum diteliti. Kedua, Penelitian ini mengumpulkan data primer melalui penyebaran kuesioner dengan sedikit wawancara sehingga data yang diperoleh kurang maksimal. Ketiga, pada saat pengisian kuesioner ada beberapa responden yang melakukan penolakan mengisi kuesioner karena waktu terburu-buru serta ada yang tidak mencantumkan data lengkap formulir kuesioner. Keempat tidak menutup kekurangan yang ada dalam penelitian ini karena hanya dilakukan dalam jangka waktu beberapa bulan. Serta Kelima,standar variabel penelitian ini hanya didasarkan keputusan pembelian ulang melalui kepuasan konsumen sehingga acara penilaian tersebut ada potensi bias dalam data yang dihasilkan.

\section{SARAN}

a. Kualitas Produk berpengaruh terhadap kepuasan konsumen tetapi penelitian ini menunjukkan kualitas produk belum atau tidak berpengaruh signifikan terhadap kepuasan konsumen. Karena produk yang dijual mempunyai kualitas yang tinggi.

b. Kualitas Pelayanan lebih diperhatikan kembali dengan pelayanan prima dan menyeluruh untuk memudahkan konsumen dalam berbelanja sehingga merasa puas karena mendapatkan pengalaman yang menyenangkan.

c. Bagi peneliti selanjutnya, hendaknya perlu dilakukan dengan cara memperdalam atau mengembangkan variabel penelitian, sehingga bisa diperoleh temuan lainnya bagi pengembangan ilmu pengetahuan. 


\section{DAFTAR PUSTAKA}

Adam, M. (2015). Bandung: Manajemen Pemararan Jasa Alfabeta

Arief, M. (2007). Pemasaran jasa dan kualitas pelsyanan. Malang : banyumedia publishing.

Arikunto, S. (2016). Prosedur Penelitian Suatu Pendelsaten Praktik. Jaksrta : Rineka Cipta

Arikunto, S. (2016). Metode Penelitian. Jakarta : Bumi Alsara.

Arisutha, D. (2005). Dimensi Kuslitas Pelayanan. Gramedia.

Badri, M. (2011). Pengaruh Dimensi Kualitas Produk Terhadap Kepuasan Nasabah Perbankan Jumal Imiah Orasi Bisnis ke-VI.

Gama, Rustiarini, dan Anggraini. (2016). Pengaruh Lokasi, Fasilitas, dan Pelavanan Terhadap Keputuan Pembelian Studi Pada Parar Seni Gusang Subervati), Vol. 11, No.1.

Ghozali, I. (2011). Apliksai Anslisis Multivariate dengan Program IBM SPSS 19. Semarang : Badan Penerbit Universitas Diponegoro.

Ghozali, I. (2012). Anslisis Multivariate dengan Program SPSS. Edisi-3. Semarang : Badan Penerbit UNDIP.

Ghozali, I. (2016). Aplikasi Anslisis Multivariate dengan Program SPSS. Edisi Ke Tujuh. Semarang : Badan Penerbit Universitas Diponegoro.

Gujarati. (2007). Eksonometrika Dasar. Jaksarta : Erlangga

Handolso. (2002). Manajemen Pemasaran. Jakarta : Badan Penerbit IPWI.

Harsalim den Sugiharto. (2015). Analisis Pengaruh Product Quality, Price, dan Promotion Terhadap Purchare Dntention Mobil Tovota Alpard di Surabqua Junal Manajemen Pemasaran Petra, Vol.3, No. 1.

Istiatin. (2018). Surakarta : Metodologi Penelitian. UNIBA Press.

J. Supranto. (2006). "Pengukuran Tingkat Kepusasn Pelanggan Untuk Menaiklkan Pangas Pasar", Cetakan Kedua, Rinelka Cipta.

Kasmir. (2017). Customers Service Excellent :Teori dan Praktik, Jakarta : PT Raja Grafindo Perasia

Kotler. (2002). Manajemen Penasaran : Jilid 1. Edisi Milenium. Jakarta : Prehallindo.

Kotler. (2011). Manajemen Pemasaran : Analisis Perencanaan, Implementasi dan Pengendalian, (alih bahasa : Hendro Teguh dan Rony A. Rusli) Jilid 2, Jakarta : Prenhalindo. 
Kotler dan Amstrong. (2008). Jalkarta: Prinsip-prinsip Pemasaran, Jilid 1, Erlangge.

Kotler dan Amstrong. (2012). Prinsip-PrinsipPemasaran. Edisi 8 Jilid 1 dan 2. Jakarta : Erlangga

Maryam, S. (2015). Statistik Induktif. Surakarta : Uniba Press.

Maryam, S. (2018). Metodologi Penelitian. Surakarta : Uniba Press.

Moenir. (2015). Manajemen Pelayanan Umum di Indonesia. Jakarta : Bumi Alsara.

Mongkao, Kawet, dan Sepang. (2017). Pengarwh Kualitas Produk Harga dan Tempat Tehadap Kepwasan Konswnen Pada Pasar Tradisional Remboken Studi Kasus Pada Mastarakat Desa Sinuian Kec. Rembokenj. Junal EMBA., Vol 2, No. 2, Hal 2469-2477.

Noto dan Hakim . (2016). Analisis Pengarwh Harga Produk dan Kualitas Produk terhadap Kepuasan Pelanggan (Studi Kasus Jasa Motor Alin. Motor Semarang). Among Makarti., Vol. 9, No.17.

Nugraha dan Sugiarto. (2016). Analisis Pengarih Kualitas Pelavanan dan Keservaian Harga Terhadap Kepurusan Pembelian Ulang Dengan Kepuas an Konswmen Sebagai Variabel Intenvening. Jwnal Diponegoro of Moragement, Vol. 5, No. 3.

Pride, W.M., and Ferrel. (2010). Morketing. Fiftinth Edition Canada : South Western Duternational Edition.

Purba den Sulistyono. (2013). Penganih Pelquanan Kualitas Produk terhacep Lovalitas Pelanggan Jwnal Imiah ManajemenKesarwan, Vol 1, No.1.

Pure. (2013). Lokasi, Keberagaman Produk Harga dan Kualitas Pelavanan Pengarwhya Terhadap .Lnat Beli Pada Pasar Tradisional Bersehati Calaca Jimal E.MBA, Vol.1,No.3, Hal. 273-283.

Purwanto. (2010). Komunikasi Bisnis Edisi Keempat. Erlangga .

Ralkhman dan Rahayu. (2017). Pengarwh Kualitas Produk Promosi, dan Harga Terhadap Keputusan Pembelian Variasi Audio Mobil di Subw Audio Workhop Punsokerto. Junal Monajemen dan Bisnis Media Elonomi, Volume XVII, No. 1.

Saputra (2015). Pengarwh Lohasi, Kualitas Produk dan Kwalitas Pelavanan Terhadap Kepwasan Konswnen Pasar Tradisional Studi Kasus Pasap Tradisional di Medan Johory. Jwnai Manajemen Bisnis, Volume 23, No.1.

Sari dan Andjarwati . (2018). Pengaruh Kualitas Produk dan Harga Terhadap Lovalitas Dengan Kepwasan Sebagai Variabel Dutenening Studi Pada 
Konswnen Biskuit Oreo di Carrefow Swrabqua). Jurnal Imu Manajemen , volume 6, No. 1 .

Sciffman dan Kanuk. (2007). Perilaku Konaumen. Edisi Kedua Jakarta : PT Indeks Gramedia

Sciffman, Lson G den Laslie L.Kanul. (2000). Customer Behaviour : Fifth Edition. New Jersey. Prentice-Hall Inc.

Sembiring, Suharyono, den Kusumawati. (2014). Pengaruh Kualitas Produk Dan Kualitas Pelavanan Terhadap Kepuasan Pelanggan Daiam Membentuk Lovalitas Pelanggan Studi Pada Pelanggan Mcdonald's Mf Havono Malang). Jumal Aaministrasi Bisnis (JAB), Vol. 15, No. 1.

Sugiyono. (2009). Metode Penelitian. Bandung : Alfabeta

Sugiyono. (2013). Metodelogi Penelitian Kuentitatif, Kuslitatif dan R\& D. Bandung : Alfabets.

Sugiyono. (2015). Metode Penelitian Kombinasi (Mix Methods). Bandung : Alfabeta.

Swasta, Basu \& Handoko, Hani. (2011). Manajemen Pemasaran-Analisis Perilaku Konsumen. Yogyalkarta : BPFE.

Tjiptono, Fandy. (2008). Strategi Pemasaran. Yogyalkarta : ANDI.

Tumbel dan Rate. (2015). Pengaruh Bawran Pemasaran Terhadap Keputusan Pembelian di Parar Tradisional (Studi padaPasar Tradisional di Kota Manado). Jumal LPPM Bidang EkoSosBudKum, Vol. 2,No. 2.

Umboh dan Tommy. (2016). Pengarwh Harga Tempat, Produk Terhadap Keputuran Pembelian di Pasay Tradisional Airmididi. Jumal Berkala Imiah Efisiensi, volume 16, No. 04.

Utama dan Ngatno. (2017). Pengarwh Keragaman Produk dan Kualitas Pelquanan Terhadap Keputuran Pembelian Ulang melalui Kepuasan Konswnen Sebagai Variabel Dutervening (Studi Pada Konswmen Gelae? Mall Ciputra Semarang). Jumal Administrasi Bisnis .

Utami dan Saputra (2017). Pengaruh Harga Dan Kualitas Produk Terhadap Minat Beli Squwan Organik Di Pasar Sambar Medan Jurnal Niaganan , Vol. 6 , No 2 .

Yanuar, Qomariah, dan Santoso. (2017). Dampak Kualitas Produk Harga Promosi dan Kualitas Pelquanan Tephadap Kepuasan Pelanggan Optik Martin Cabang Jember. Jurnal Marajemen dan Bisnis Indonesia . 